\title{
VLIV COVIDU-19 NA EXISTENCI ZÁVAZKU A PLNĚNÍ SMLUVNÍCH POVINNOSTÍ*
}

\author{
PETR TOMÁŠEK, KLÁRA HURYCHOVÁ
}

\begin{abstract}
The Influence of Covid-19 on the Existence of Obligations and the Fulfilment of Contractual Duties

Several legal provisions respond to a substantial change in circumstances in contractual relationships. The performance of a contract may be impossible initially at the time of contract creation, or, more frequently, may become impossible within the existence of the contract. While the former results in invalidity of the contract itself, the latter leads to a discharge of the obligation created by the contract. However, the impossibility of performance is to be distinguished from such a change in circumstances that merely creates a gross disproportion in the rights and duties of the parties by disadvantaging one of them either by disproportionately increasing the costs of the performance or disproportionately reducing the value of the performance. On this basis, the affected party may seek a renegotiation of the contract and the court may decide to revise the obligation in restoring the balance of rights and duties of the parties.
\end{abstract}

Keywords: obligation; impossibility of performance; substantial change in circumstances; covid-19; pandemic

Klíčová slova: závazek; nemožnost plnění; podstatná změna okolností; covid-19; pandemie

DOI: $10.14712 / 23366478.2021 .17$

\section{1. ÚVOD}

Pandemie viru covid-19 zasáhla snad všechny společenské vztahy, včetně vztahů právních. Zákonodárce na nové poměry zareagoval přívalem veřejnoprávních opatření, která kladou zvýšené nároky nejen na jejich primární adresáty, ale též na odbornou veřejnost. Stěžejním úkolem se tak stala analýza současného stavu a předkládání možných řešení otázek, které v souvislosti s pandemií vyvstaly.

Vedle nejrůznějších kompenzací a úlev tvoří bezesporu významnou oblast posouzení dopadů pandemie na soukromoprávní a především smluvní vztahy, zejména pokud jde o platnost jejich vzniku a možnosti, jak na nové podmínky reagovat. Občanský zákoník obsahuje vlastní obecnou úpravu zahrnující celou škálu (nejen) smluvních závazků,

Tento článek zohledňuje právní stav k 31. 3. 2021 a vznikl v rámci projektu UNCE/HUM/034 Závislá práce v 21. století - otázky a výzvy na Právnické fakultě Univerzity Karlovy. 
bez ohledu na konkrétní smluvní typ. ${ }^{1}$ Dopad na závazky pracovněprávní je, s ohledem na speciální úpravu překážek v práci na straně zaměstnance i zaměstnavatele, značně omezený. ${ }^{2}$ I tak ale obecná úprava představuje významný korektiv pro řadu nikoli nepodobných vztahů, jejichž obsahem je povinnost dlužníka vykonat pro věřitele konkrétní činnost (poskytnout službu) či mu takovou činnost alespoň umožnit.

Smluvní strany si pak s ohledem na pandemii kladou především následující stěžejní otázky:

1. Vznikl na základě smlouvy platný závazek?

2. Trvá tento závazek i za nových okolností?

3. Lze se pro nové okolnosti domáhat změny závazku?

\section{POČÁTEČNÍ A NÁSLEDNÁ NEMOŽNOST PLNĚNÍ}

\subsection{NEMOŽNOST PLNĚNÍ}

Zásadní dopad na vznik závazku či jeho další trvání má tzv. nemožnost plnění. ${ }^{3} \mathrm{Z}$ časového pohledu rozlišujeme nemožnost počáteční a následnou (dodatečnou), z pohledu věcného pak nemožnost plnění faktickou a právní.

Fakticky nemožným je plnění, které vzhledem k jeho povaze považuje za „fyzicky“ nemožné každý rozumný člověk. ${ }^{4}$ Ilustračně půjde o plnění smlouvy, dle níž se zasílatel domněle zaváže, že pro př́ikazce zajistí přepravu zásilky v době, která je objektivně neuskutečnitelná. ${ }^{5}$ Na právní nemožnost plnění naproti tomu usuzujeme v kontextu právních předpisů (zákonů i podzákonných norem) či rozhodnutí orgánů veřejné moci, které konkrétní plnění zakazují. ${ }^{6}$

1 Některé smluvní typy nicméně obsahují vlastní dílčí úpravu týkající se nemožnosti plnění (např. § 2208 odst. $1, \S 2337$ odst. 2 či $§ 2627$ odst. 1 o. z.).

2 Srov. rozsudek Nejvyššího soudu ze dne 11. 4. 2008, sp. zn. 21 Cdo 1083/2017, ze dne 7. 8. 2018, sp. zn. 21 Cdo 673/2018.

3 V tuto chvílí pomíjíme, že $\S 2006$ odst. 1 o. z. gramaticky váže „,nemožnost plněni““ na „,nesplnitelnost dluhu “, nebot' v prostém jazykovém odlišení a v kontextu uvedeného ustanovení v takovém odlišení stěží nacházíme jakýkoli racionální smysl. Ostatně i obchodní zákoník v § 352 a násl. užíval obojího pojmosloví v zásadě promiscue. Měla-li by snad podle některých názorů ,,nesplnitelnost“ oproti ,nemožnosti“ navíc zahrnovat také právní nedovolenost, vytvářel by se podle našeho názoru nedůvodný rozdíl v posuzování situací, kdy právní nedovolenost byla dána od počátku a kdy nastala až následně.

4 Srov. ŠILHÁN, J. in: HULMÁK, M. a kol. Občanský zákoník. V, Závazkové právo: obecná část (\$ 1721-2054): komentár̆. Praha: C. H. Beck, 2014, s. 1221.

5 Obdobně, byt' nikoli přímo ve vztahu k pandemii, by šlo o fakticky nemožné plnění tehdy, pokud by se prodávající např. zavázal, že na kupujícího převede bytovou jednotku, která však nakonec nebyla vybudována (rozsudek Nejvyššího soudu ze dne 27. 8. 2020, sp. zn. 25 Cdo 3788/2019), nebo že převede na prodávajícího vlastnické právo k akciím, které ovšem vůbec neexistují (rozsudek Nejvyššího soudu ze dne 26. 4. 2018, sp. zn. 29 Cdo 2601/2016).

6 Např. rozsudek Nejvyššího soudu ze dne 22. 5. 2003, sp. zn. 28 Cdo 870/2003, ze dne 28. 2. 2017, sp. zn. 33 Cdo 45/2015. Důvodem počáteční právní nemožnosti plnění může ale také být jiné soukromoprávní ujednání - např. v případě uzavření nájemní smlouvy $\mathrm{k}$ bytu, který je již užíván na základě jiné nájemní smlouvy (např̀. rozsudek Nejvyššího soudu ze dne 29. 5. 1997, sp. zn. 3 Cdon 120/96, či usnesení téhož soudu ze dne 9. 6. 2009, sp. zn. 26 Cdo 2238/2008). 
Nemožnost plnění se posuzuje objektivně. ${ }^{7}$ Podle $§ 2006$ odst. 1 o. z. se plnění nestane nemožným, pokud jej lze splnit např. pomocí jiné osoby, přičemž shodný závěr je třeba dle našeho názoru z povahy věci učinit i ve vztahu k posuzování nemožnosti počáteční. Z objektivní povahy nemožnosti plnění plyne i to, že za nemožné nelze považovat plnění, kterému lze dostát za ztížených podmínek či s většími náklady (srov. § 2006 odst. 1 o. z.). Na takovou změnu okolností pamatují jiná ustanovení, která jsou rovněž předmětem této stati (např. $\$ 1765$ o. z.).

\subsection{POČÁTEČNÍ NEMOŽNOST PLNĚNÍ}

Počáteční nemožnost plnění nastává v situacích, kdy je již od počátku, tj. od vzniku právního jednání, zřejmé, že plnění bude nemožné. ${ }^{8}$ Právní jednání, které mělo založit povinnost k plnění od počátku nemožnému, sankcionuje zákon absolutní neplatností (§ 580 odst. 2 a $§ 588$ o. z.). ${ }^{9}$ Ta působí ze zákona (ex lege), od počátku (ex tunc) a soud k ní přihlédne i bez návrhu, aniž by se jí musela kterákoli smluvní strana dovolat, a to dokonce i tehdy, pokud by ji snad některá sama způsobila. ${ }^{10}$

Uvedená povinnost soudu by však neměla vést smluvní strany k procesní rezignaci a v prosté spolehnutí se na to, že soud nemožnost plnění v civilním řízení sám zjistí. Jak totiž Nejvyšší soud vysvětlil již ve svém rozsudku ze dne 8. 2. 2001, sp. zn. 22 Cdo 752/99, přihlédne soud k absolutní neplatnosti právního jednání jen v případě, kdy skutečnosti zakládající absolutní neplatnost tohoto právního jednání (tedy skutečnosti zakládající nemožnost plnění, které je předmětem právního jednání) vyjdou v řízení najevo.

Mohlo by se tak zdát, že smluvní strany, na něž pandemie dopadla, musí ve vztahu k prokazování skutečností zakládajících nemožnost plnění dbát zvýšené opatrnosti. Dle našeho názoru však nebudou tyto případy časté. Nejistota ve smluvních vztazích způsobená pandemií bude v kontextu nemožnosti plnění hrát roli zejména ve vztahu $\mathrm{k}$ přijatým veřejnoprávním opatřením, která je však soud povinen znát v rámci zásady iura novit curia. Ostatně i s ohledem na obecný předpoklad racionálního úmyslu smluvních stran (zavazovat se platně) přichází v praxi v úvahu především nemožnost plnění následná.

Sporným se ovšem může jevit, jak nahlížet na situace, kde se smluvní strany zaváží $\mathrm{k}$ plnění, které je již v době právního jednání nedovolené, avšak v dobré vîre, že veřejnoprávní opatření bude do okamžiku, kdy má k plnění dojít, zrušeno či změněno.

7 Např. § 2006 odst. 1 o. z. (,... s pomocí jiné osoby“) či usnesení Nejvyššího soudu ze dne 30. 7. 2003, sp. zn. 25 Cdo 1569/2001. Výjimku z tohoto pravidla tvoří plnění, která jsou vázána na osobní vlastnosti dlužníka (DĚDIČ, J. a kol. Obchodní zákoník: komentářr. Díl IV, § 221 - § 775. Praha: BOVA POLYGON, 2002, s. 3383).

8 Srov. např. rozsudek Nejvyššího soudu ze dne 13.9. 2007, sp. zn. 28 Cdo 2789/2007, či ze dne 18. 5. 2016, sp. zn. 33 Cdo 603/2015.

9 Zatímco v § 580 o. z. hovoří zákonodárce o „proste“ “ nemožnosti plnění, v § 588 o. z. pracuje s nemožností plnění, která je dána „od počátku“. To by mohlo znamenat, že zatímco nemožnost plnění daná při právním jednání způsobuje neplatnost absolutní, nemožnost plnění vzniklá až po právním jednání způsobuje pouze neplatnost relativní. Takový výklad však dle našeho názoru nemůže obstát, nebot' pro následnou nemožnost plnění normuje zákonodárce specifický následek v podobě zániku závazku (§ 2006 odst. 1 o. z.). Soudíme proto, že $\$ 580$ o. z. je třeba vnímat jako duplicitní, a překlenout tuto duplicitu výkladem.

10 Srov. usnesení Nejvyššího soudu ze dne 20. 12. 2001, sp. zn. 26 Cdo 1668/2000. 
Soudíme, že na taková právní jednání nelze automaticky pohlížet jako na od počátku neplatná, nebot' dle relativně ustálené (byt' kusé) judikatury musí jít v př́ípadě počáteční nemožnosti plnění nejen o nemožnost objektivní, ale i trvalou. ${ }^{11}$

Teorie přitom nevykládá pojem trvalosti jako překážku absolutní povahy. Rozhodující je, zda lze či nelze s přihlédnutím ke všem dostupným informacím realisticky očekávat, že překážka v budoucnu pomine. Pozdější nečekané a překvapivé odpadnutí překážky tak nemá na zánik závazku vliv. ${ }^{12}$

Veřejnoprávní opatření reagující na pandemii jsou přitom běžně přijímána na dobu určitou a $\mathrm{v}$ této době navíc mnohdy měněna, at' již zpř́ísňována, či rozvolňována. Smluvní strany tak mohou konkrétní vývoj očekávat, a proto zejména u plnění, k nimž má dojít s výraznějším časovým odstupem, nebude zpravidla možné automaticky uzavřít, že veřejnoprávní opatření představuje překážku trvalé povahy. ${ }^{13}$

Jakkoli pak nepopíráme otevřenost a jistou složitost této otázky, kloníme se v uvedených případech spíše k posuzování ve světle nemožnosti plnění následné, případně též v kontextu podmínek právního jednání (§ 548 o. z.).

\subsection{NÁSLEDNÁ NEMOŽNOST PLNĚNÍ}

Následná nemožnost plnění nastává až po vzniku závazku (typicky uzavření smlouvy). Její podstatou je vznik okolnosti, v jejímž důsledku se plnění následně stane nemožným, ačkoli v době vzniku závazku objektivně splnitelné bylo. ${ }^{14} \mathrm{~V}$ důsledku následné nemožnosti plnění zaniká závazek vzniklý z právního jednání, ${ }^{15}$ nikoliv právní jednání samotné. ${ }^{16}$ Splatnost dluhu, který má být splněn, není přitom pro zánik závazku dle dikce zákona rozhodující. Závazek tak zaniká i v případě dluhů dosud nesplatných.

To však neznamená, že by čas plnění byl pro trvání závazků zcela bezvýznamný. Pro řadu z nich bude typické sjednání doby, v níž je dlužník povinen plnit, např. přesně specifikovaným časovým obdobím. Trvalost nově vzniklé překážky je tak třeba posuzovat právě ve vztahu k zamýšlené době plnění. ${ }^{17}$ I překážka, u níž lze očekávat její pominutí (např. pozděǰš́ zrušení veřejnoprávního opatřenî), tak bude považována za trvalou a působit zánik závazku, jestliže nelze realisticky očekávat, že by do předpokládané doby plnění měla odpadnout.

11 Usnesení Nejvyššího soudu ze dne 30. 7. 2003, sp. zn. 25 Cdo 1569/2001 (byt' bez bližší specifikace ,trvalosti“), a na něj povětšinou navazující např. rozsudek Nejvyššího soudu ze dne 8. 12. 2009, sp. zn. 28 Cdo 2170/2009, ze dne 26. 8. 2014, sp. zn. 23 Cdo 2368/2012, ze dne 27. 9. 2016, sp. zn. 23 Cdo 3865/2016, ze dne 18. 11. 2015, sp. zn. 26 Cdo 2907/2015.

12 ŠILHÁN, $c . d$., s. 1222. Podobně i Nejvyšší soud nap̌r. ve svém rozsudku ze dne 28. 6. 2007, sp. zn. 33 Odo 605/2005, opatrně připustil, aby zánik závazku výjimečně způsobila i překážka pouze přechodná.

13 Srov. také usnesení ze dne 24. 7. 2012, sp. zn. 32 Cdo 1491/2011, v němž Nejvyšší soud dovodil, že ani u veřejnoprávního opatření, které nebylo v době jeho vydání omezeno na určitou dobu, nelze automaticky předjímat, že není jen dočasné povahy, nebot' z okolností a povahy veřejnoprávního opatření může plynout jiný závěr.

14 Např. rozsudek Nejvyššího soudu ze dne 27. 11. 2003, sp. zn. 28 Cdo 1872/2003.

15 Povinnost k plnění (dluh) zanikne okamžikem, kdy překážka nastala (viz napřr. rozsudky Nejvyššího soudu ze dne 25. 1. 2012, sp. zn. 32 Cdo 3334/2010, či ze dne 26. 11. 2014, sp. zn. 33 Cdo 3069/2014.

16 Rozsudek Nejvyššího soudu ze dne 26. 3. 2008, sp. zn. 32 Odo 1087/2006.

17 Srov. „důraz“ na povahu závazku v rozsudku Nejvyššího soudu ze dne 30. 5. 2012, sp. zn. 25 Cdo 4850/2009, resp. „důraz“ na obsah závazku v usnesení téhož soudu ze dne 18. 11. 2015, sp. zn. 26 Cdo 2907/2015. 
V důsledku četné proměnlivosti veřejnoprávních opatření může po uzavření smlouvy docházet také k nejrůznějším změnám okolností. Např. si lze představit, že se smluvní strana zaváže k plnění, které je ke dni uzavření smlouvy dovolené, následně se však $\mathrm{v}$ důsledku veřejnoprávního opatření stane plnění zakázaným, aby bylo ještě před splatností dluhu opětovně dovoleno. I na tyto situace je nutno pohlížet optikou upínající se ke dni vzniku překážky a k předpokládané délce jejího trvání. Bude-li možné přri vzniku překážky usuzovat, že do sjednané doby plnění nepomine, závazek zanikne a neobnoví se ani tehdy, pokud by před touto dobou překážka nakonec pominula. ${ }^{18}$ Ostatně stěží by mohlo být smyslem právní úpravy, aby byly smluvní strany uváděny v déletrvající (a třeba i proměnlivou) nejistotu a dlužník snad staven do situace, kdy bude př́ípadný zánik jeho povinnosti plnit zř̉ejmý až tehdy, kdy pro něj již řádné a včasné plnění nebude možné (\$10 odst. 2 o. z.).

Uved’me dále, že k zániku závazku pro následnou nemožnost plnění dochází ex lege, aniž by dlužník nebo věřitel byli povinni vzájemně čehokoli činit. Zákon nicméně dlužníkovi ukládá, aby poté, co se o nemožnosti plnění dozvěděl nebo dozvědět musel, oznámil tuto skutečnost věřiteli, jinak odpovídá za škodu mu způsobenou v důsledku, že nebyl o nemožnosti plnění včas vyrozuměn (\$ 2008 o. z.). ${ }^{19}$ Jde o projev širokého principu poctivosti v právních vztazích (\$ 6 o. z.), který zahrnuje rovněž loajalitu vůči smluvnímu partnerovi, tedy potřebnou ohleduplnost a přiměřený respekt $\mathrm{k}$ jeho zájmům. ${ }^{20}$

Je nicméně otázkou, jak uvedenou povinnost dlužníka posuzovat ve vztahu k veřejnoprávním opatřením, která mohou a musí být věřiteli známa. Soudíme, že v těchto případech by se pasivní věřitel s ohledem na specifický charakter pandemie dopustil přinejmenším porušení prevenční povinnosti (\$ 2900 o. z.). Přesto lze z opatrnosti doporučit, aby i přesto dlužník věřitele řádně informoval.

\section{ZMAŘENÍ ÚČELU SMLOUVY A HOSPODÁŘSKÁ OBTÍŽNOST PLNĚNÍ}

S nemožností plnění úzce souvisí i okolnosti, pro které se plnění nestane objektivně nemožným, avšak způsobí významný zásah do postavení stran závazku. Jde především o zmaření účelu, za nímž byla smlouva uzavřena, případně o vytvoření zvlášt' hrubého nepoměru zvýhodněním nebo znevýhodněním některé ze smluvních stran.

Zmaření účelu smlouvy výslovně znala dřívější úprava obchodního zákoníku. Ustanovení § 356 odst. 1 ObchZ zakládalo dotčené straně právo odstoupit od smlouvy, pokud byl v důsledku podstatné změny okolností zmařen základní účel, který byl ve smlouvě výslovně ${ }^{21}$ vyjádřen. Odstoupení od smlouvy nicméně nezbavovalo odstoupivší

18 Srov. také rozsudek Nejvyššího soudu ze dne 10. 4. 2007, sp. zn. 32 Odo 795/2006.

19 Vzhledem ke složitosti obchodního života může být sjednané plnění důležité např. pro plnění povinností věřitele vůči jiným partnerům.

20 Srov. také rozhodnutí Nejvyššího soudu Kanady ze dne 13. 11.2014 ve věci Bhasin v. Hrynew (2014 SCC 71).

21 Lze hodnotit jako nekoncepční, proč podle obchodního zákoníku mohlo dojít k odstoupení od smlouvy pro zmaření jejího účelu jen tehdy, byl-li zmařený účel ve smlouvě výslovně vyjádřen ( 356 odst. 1 ObchZ), zatímco při odstoupení od smlouvy v situacích, kdy se nemožným stala jen část plnění (\$ 352 odst. 3 ObchZ), postačilo, aby byl účel uzavření smlouvy stranám znám. K potvrzení požadavku 
stranu povinnosti nahradit škodu, která jí nesplněním smlouvy v důsledku odstoupení vznikla, tj. skutečnou škodu i ušlý zisk ( $\$ 357$ a $\$ 359$ ObchZ).

Zmíněné ustanovení tedy umožňovalo částečné, nikoli však úplné, odvrácení nepříznivých následků souvisejících se zmařením účelu smlouvy. V poměrech pandemie uved’me modelový příklad, kdy pronajímatel pronajme nájemci - hokejovému klubu kluziště za účelem tréninkové přípravy hokejového mužstva. Došlo-li by po uzavření smlouvy, jejíž účel v ní byl výslovně vyjádřen, k přijetí opatření, které zakáže venkovní sportovní činnost za účasti více než 2 osob, pak by hokejový klub mohl od smlouvy pro zmaření jejího účelu odstoupit. V takovém případě by hradil pronajímateli alespoň ušlý zisk, tedy částku odpovídající rozdílu mezi původně sjednaným nájemným a náklady, které by pronajímatel v souvislosti s nájmem - např. přípravou a provozem kluziště musel př́ípadně vynaložit (osvětlení, rolba, přítomnost pracovníků údržby atd.).

Na rozdíl od obchodního zákoníku, stávající úprava v obecných ustanoveních na zmaření účelu smlouvy výslovně nepamatuje. To klade na smluvní strany zvýšené nároky v tom, aby přesně specifikovaly, při jakých okolnostech bude moci některá z nich od smlouvy odstoupit (\$2001 o. z.).

Není-li takového ujednání o účelu smlouvy, lze zvažovat alespoň postup dle $§ 1765$ odst. 1 o. z. Ten zakládá dotčené straně právo požadovat obnovení jednání o smlouvě, pokud došlo ke změně okolností tak podstatné, že založila v právech a povinnostech stran zvlášt' hrubý nepoměr znevýhodněním jedné ze stran bud’ neúměrným zvýšením nákladů plnění, anebo neúměrným snížením hodnoty předmětu plnění.

Soudíme, že právě „neúměrné snižení hodnoty předmětu plněni“ " míríi na situace, kdy je účel smlouvy zmařen. Ilustračně lze opět využít modelový př́íklad uvedený shora, avšak s drobnou odchylkou - překážkou plnění není pandemie, ale stávka hráčských odborů, v jejímž důsledku dojde $\mathrm{k}$ přerušení soutěže. V takovém př́ípadě může nájemce technicky vzato kluziššc dle své libosti využít, avšak v důsledku hráčské stávky je pro něj užití kluziště zcela bezvýznamné. Hodnotu předmětu plnění je přitom dle našeho názoru nutno vnímat především subjektivně a ve vztahu ke straně, jíž má být plnění poskytnuto.

Pokud jde o první část hypotézy (neúměrné zvýšení nákladů plnění), § 1765 odst. 1 o. z. reaguje na případy tzv. hospodářské obtížnosti plnění. K ní je třeba uvést, že prosté zvýšení nákladů plnění samo o sobě neznamená ani zánik závazku pro nemožnost plnění (§ 2006 odst. 1 o. z.), ${ }^{22}$ ani vznik práva domáhat se obnovení jednání o smlouvě (§ 1764 o.z.).

Citlivé nalézání hranice mezi „prostým“ nepoměrem, který je smluvní strana povinna bez dalšího nést, a „zvlášt’ hrubým “ nepoměrem, u nějž se lze domáhat obnovení jednání o smlouvě, bude významným úkolem doktríny i judikatury. V kontextu výkladu jiných právních institutů, které reagují na nepřiměřenost ve vzájemných plněních (\$1793 a násl. o. z.), soudíme, že obnovit jednání o smlouvě budou strany povinny zásadně

výslovného uvedení účelu smlouvy pak viz usnesení Nejvyššího soudu ze dne 17. 12. 2014, sp. zn. 23 Cdo 2455/2011. Srov. také obecné posuzování účelu právního jednání dle rozsudku Nejvyššího soudu ze dne 11. 2. 2004, sp. zn. 22 Cdo 2119/2003.

22 Opačný závěr by ostatně odporoval shora uvedené podmínce, aby šlo o nemožnost plnění objektivní. K závěru o trvání závazku i při obtížnosti plnění srov. v režimu dřívější úpravy také rozsudek Nejvyššího soudu ze dne 23.9. 2009, sp. zn. 33 Cdo 1787/2007, ze dne 28. 2. 2017, sp. zn. 33 Cdo 45/2015, či usnesení téhož soudu ze dne 5. 8. 2013, sp. zn. 28 Cdo 420/2013, ze dne 27. 3. 2020, sp. zn. 24 Cdo 3315/2019. 
tehdy, jestliže se hodnota plnění nebo náklady na něj změní do té míry, že nepoměr mezi hodnotou vzájemných práv a povinností bude přinejmenším více než dvojnásobný. ${ }^{23}$

Ačkoli komparativní výklad tomuto závěru nasvědčuje, máme za to, že jej nelze brát za absolutní a že je třeba vždy přihlédnout ke specifickým okolnostem konkrétního př́padu, a to i subjektivní povahy (např. k mîre negativních dopadů na smluvní stranu a její další činnost).

Lze si také položit otázku, zda by zcela neúměrná změna hodnoty plnění $v$ důsledku podstatné změny okolností nemohla znamenat zánik závazku pro nemožnost plnění z důvodu jeho „zjevné hospodářské nesmyslnosti “. Již v rozsudku ze dne 28. 6. 2007, sp. zn. 33 Odo 605/2005, Nejvyšší soud naznačil, že „prosté“ zvýšení nákladů plnění, pro nějž se smluvní strana nemůže čehokoli domáhat, nelze ztotožňovat s naprostým odhlédnutím od jejich výše, ${ }^{24}$ a otevřel tak cestu pro použití optiky následné nemožnosti plnění. Ačkoli pokládáme tento závěr za rozumný, pohříchu je spíše ojedinělým, nebot' ostatní citovaná rozhodnutí zjevnou hospodářskou nesmyslnost prŕliš nezmiňují. ${ }^{25}$ Soudíme přitom, že nově ukotvené pravidlo § 1765 o. z., které dřívější úpravy obchodního zákoníku neznalo, povede rovněž k restriktivnějšímu posuzování př́ípadů, na něž zánik závazku pro následnou nemožnost plnění dopadá. ${ }^{26}$

Dodejme pak, že i praktický význam dopadu § 1765 a násl. o. z. na smluvní vztahy je omezený. Podle $\S 1765$ odst. 1 o. z. in fine se uplatněním práva na obnovení jednání o smlouvě její smluvní strana neopravňuje k tomu, aby odložila plnění, přičemž nedohodnou-li se strany, může soud rozhodnout, že závazek změní obnovením rovnováhy práva a povinností stran (§ 1766 odst. 1 o. z.). Jinými slovy, jestliže smluvní strany nenaleznou shodu na změně závazku, pak je dotčená strana postavena před relativně dlouhou a nikoli jasně předvídatelnou cestu. I proto plédujeme za citlivé posuzování specifických okolností konkrétních případů, a ne za kazuistické hledání př̌sné hranice, která oddělí prostý nepoměr od nepoměru zvlášt' hrubého. Zajímavé bude sledovat i budoucí výklad ustanovení § 1765 odst. 2 OZ, které může v konkrétních okolnostech zapůsobit zvláště tvrdě.

\footnotetext{
JUDr. Petr Tomášek, Ph.D.

Právnická fakulta Univerzity Karlovy

tomasekp@prf.cuni.cz

JUDr. Bc. Klára Hurychová, Ph.D.

Právnická fakulta Univerzity Karlovy

kulhanko@prf.cuni.cz
}

\footnotetext{
23 K inspiračnímu zdroji $§ 1793$ odst. 1 o. z., který počítá nikoli s „,hrubým nepoměrem “, nýbrž nepoměrem „zvlášt’ hrubým “, viz ROUČEK, F. - SEDLÁČEK, J. a kol. Komentář k československému obecnému zákoníku občanskému a občanské právo platné na Slovensku a v Podkarpatské Rusi. Díl 4., (\$\$ 859 až 1089). Praha: Právnické knihkupectví a nakladatelství V. Linhart, 1936, s. 394 a násl.

24 Poněkud odlišně však srov. odůvodnění rozsudku Nejvyššího soudu ze dne 14. 9. 2017, sp. zn. 26 Cdo 4910/2016.

25 Což samozřejmě může být částečně dáno i skutkovým stavem, z něhož vycházejí.

26 Obdobně zřejmě též ŠILHÁN, $c$. $d$., s. 224.
} 